\title{
Cikkismertetés: Az elektronikus cigarettával kapcsolatos bővülő ismeretek módszeres áttekintése az újabb bizonyítékok alapján
}

\author{
Article review: The Evolving Landscape of e-Cigarettes: \\ A Systematic Review of Recent Evidence
}

$\begin{array}{ll}\text { Ismertető: } & \text { Cselkó Zsuzsa } \bowtie \\ & \text { Országos Korányi Pulmonológiai Intézet, Budapest }\end{array}$

Ismertetett cikk: Bozier J, Chivers EK, Chapman DG, Larcombe AN, Bastian N, Masso-Silva J, Byun M, McDonald CF, Alexander Crotty LE, Ween MP. The Evolving Landscape of e-Cigarettes: A systematic review of recent evidence. Chest, 2020; 157(5):1362-1390. https://doi.org/10.1016/j.chest.2019.12.042.

Beküldve: $\quad$ 2020. 05. 18.

doi: $\quad 10.24365 /$ ef.v61i3.603

Kulcsszavak: e-cigaretta; dohányzás; leszokás

Keywords: e-cigarettes; smoking; cessation

Ma már közismert és elfogadott tény, hogy a dohányzás súlyosan veszélyezteti az egyén egészségét, és komoly gondot jelent a társadalom gazdasági terheinek növelése miatt. A különböző hatóságok fellépésének és az egészségtudatosság terjedésének köszönhetően az utóbbi, mintegy másfél évtizedben világszerte érzékelhető volt a dohányzás visszaszorulása.i Komoly gondot jelent azonban, hogy a hagyományos dohánytermékek fogyasztása érdemben nem csökken, miközben az új típusú dohány- és nikotintartalmú élvezeti termékek (elektronikus cigaretta, hevített dohánytermékek, nikotinos tasak) használata Magyarországon is terjed, ahogyan ez világszerte megfigyelhető.iii,iv
Egyes gyártók az elektronikus cigarettát (e-cigaretta) a leszokás eszközeként népszerüsítik. Aggasztó, hogy a technológiai újdonság, a sokféle, kedvelt ízesítésű termék, a dohányipar reklámtevékenysége hatására ez az eszköz vonzóvá válhat, és ösztönözheti a termék kipróbálását különösen a korábban nem dohányzó fiatalok körében.ii

Az e-cigaretta használata a 2003-as megjelenése óta világszerte exponenciálisan nő. A felnőttek 2-3\%-a rendszeresen használja, és különösen elterjedt az amerikai 16-19 évesek (5,2\%), az angol 16 év felettiek (5,5\%) és a lengyel 15-19 évesek (35\%) körében.

\footnotetext{
' National Center for Chronic Disease Prevention and Health Promotion (US) Office on Smoking and Health. The health consequences of smoking-50 years of progress. A report of the Surgeon General. Atlanta (GA): Centers for Disease Control and Prevention (US). 2014. https://www.surgeongeneral.gov/library/reports/50-years-of-progress/index.html

ii WHO Report on the Global Tobacco Epidemic, 2019. Geneva: World Health Organization; 2019. https://apps.who.int/iris/bitstream/handle/10665/326043/9789241516204-eng.pdf?ua=1

iii Bialous SA, Glantz SA. Heated tobacco products: another tobacco industry global strategy to slow progress in tobacco control. Tob Control 2018;0:1-7. doi:10.1136/tobaccocontrol-2018-054340.

iv World Health Organization Regional Office for Europe. Electronic nicotine and non-nicotine delivery systems. A brief. World Health Organization, 2020. https://www.euro.who.int/_data/assets/pdf_file/0009/443673/Electronic-nicotine-and-non-nicotine-delivery-systems-brief-eng.pdf
} 
Jelen összefoglaló a 2018-ban publikált átfogó beszámolóv óta megjelent, és a PubMed adatbázisban fellelhető, 2019. május végéig publikált ismereteket dolgozza fel. Az irodalomkutatás 2687 publikációt eredményezett, amelyből 225 került kiválasztásra. A szerzők a következő kérdésekre keresték választ az irodalomkutatás során: 1. Az e-cigaretta használatának hatásai a nemdohányzókra, 2. Az e-cigaretta használatának hatásai a dohányzókra, 3. Az e-cigaretta használatának hatásai a magas kockázatú személyekre, 4. Az ízesítő adalékanyagok egészségkárosító hatásai, 5. A nikotinmentes és a nikotintartalmú e-cigaretta hatásai, 6. Az e-cigaretta egyéb veszélyei.

\section{AZ E-CIGARETTA HASZNÁLATÁNAK HATÁSAI A NEMDOHÁNYZÓKRA}

Az amerikai lakosságra kiterjedő vizsgálatok az e-cigarettahasználat kedvező hatásának tulajdonították a dohányzók számának csökkenését. Az újabb vizsgálatok szerint a korábban nem dohányzó és e-cigarettahasználó serdülők nagyobb valószínűséggel kezdtek el dohányozni, vagy tértek át a hagyományos dohánytermékek és az e-cigaretta együttes használatára, mint az e-cigarettát nem használó fiatalok.

Egyre több eredmény bizonyítja, hogy e-cigarettahasználat során szabadgyökök képződnek, gyulladásos citokinek szabadulnak fel, amelyek sejtkárosodást idéznek elő. Ugyancsak megerősítést nyert, hogy az e-cigaretta használata gyengíti az immunrendszer kórokozókkal szembeni védekezőképességét, és elősegíti a baktériumok megtapadását és elszaporodását.

E-cigaretta használatát követően gyakrabban tapasztaltak légzőszervi tüneteket mind a korábbi dohányzók, mind a csak e-cigarettát használók, mint azok, akik egyáltalán nem éltek ezzel. Az e-cigaretta szív- és érrendszerre gyakorolt hatása egyelőre nem ismert egyértelmúen, de állatkísérletek során kimutatták az aorta és az artériák fokozott merevségét, valamint az érelmeszesedéssel együtt járó gyulladá- sos tüneteket. Ugyancsak állatkísérletek igazolták az e-cigaretta pusztító hatását a tüdő szerkezetére és a kapillárisokra, a hörgőcskék csökkent múködését, a légutak fokozott reakcióját és szűkületét.

Az e-cigarettahasználat gyakrabban jár együtt szájüregi megbetegedésekkel. Hozzájárulhat a fogíny és állkapocscsont sorvadásához és fogvesztéshez.

Az e-cigarettahasználat károsan befolyásolja a mezenchimális őssejtek múködését. Állatkísérletekben az ízesített e-cigaretta, nikotintartalomtól függetlenül is koponya- és arcdeformitásokat okozott, a nikotinmentes e-cigaretta pedig anyagcsererendellenességet idézett elő az utódállatban. Ugyancsak állatokon végzett vizsgálatokban az anyaállat e-cigaretta aeroszolnak való kitettsége rövid távú memóriazavart és hiperaktivitást okozott az utódban.

\section{AZ E-CIGARETTA HASZNÁLATÁNAK HATÁSAI A DOHÁNYZÓKRA}

Vizsgálatok szerint, egyes vegyületek ( $N$ '-nitrozonornikotin (NNN), 4-(metilnitrozamino)-1-(3-piridil)-1-butanol (NNAL) és szénmonoxid) a hagyományos cigarettánál alacsonyabb mértékben találhatók az e-cigarettában, mások (fémek) változó mértékben mutathatók ki. Egyelőre nem eldöntött, hogy a hagyományos dohányzásról az e-cigarettahasználatra való áttérés kedvezően hat-e a szívés érrendszer múködésére. A vizsgálatok többsége szerint azonban az e-cigarettahasználók esetében rosszabbak a szív- és érrendszer és a légzőrendszer múködésének paraméterei (vérnyomás, szívfrekvencia, kilélegzett szénmonoxid és nitrogénmonoxid), mint azoknál, akik addig semmit nem használtak. Mindezek alapján nem valószínú, hogy az e-cigaretta leszokást támogató eszközként való használata jobb eredményre vezet az igazoltan hatékony módszereknél (pl. nikotinpótlók), annál is inkább, mert a tanulmányok szerint az e-cigarettahasználatra áttérő dohányzók többsége hosszú távon alkalmazza az eszközt.

\footnotetext{
$\checkmark$ National Academies of Sciences, Engineering, and Medicine: Public health consequences of e-cigarettes. Washington, DC, 2018.: The National Academies Press. doi: https://doi.org/10.17226/24952.
} 


\section{AZ E-CIGARETTA HASZNÁLATÁNAK HATÁSAI A MAGAS KOCKÁZATÚ SZEMÉLYEKRE}

COPD

A korábbi és az újabb tanulmányok sem igazolták az e-cigarettára való áttérés kedvező hatását (gyulladás mérséklése, a betegség progressziójának lassítása) a dohányzó COPD betegek esetében. Az e-cigarettahasználat továbbá emelheti az akut szívés érrendszeri események előfordulásának gyakoriságát a COPD betegek körében.

\section{Asztma}

Vizsgálatok igazolták az asztma és az e-cigarettahasználat összefüggéseit. Mind az e-cigarettahasználat, mind az aeroszol passzív elszenvedése gyakrabban provokált asztmatikus tüneteket, akár már egyszeri alkalom esetében is.

\section{Várandósokra és a magzatra gyakorolt hatás}

Állatokon végzett vizsgálatok szerint az anyaállat e-cigaretta aeroszolnak való kitettsége a nikotintartalomtól függetlenül is káros hatással van az utód későbbi viselkedésére és tanulási folyamataira.

\section{AZ ÍZESÍTŐ ADALÉKANYAGOK EGÉSZSÉGKÁROSÍTÓ HATÁSAI}

Laboratóriumi vizsgálatok igazolják az ízesítő anyagok sejtkárosító és gyulladáskeltő hatását. Az utántöltő folyadékok valódi összetételére vonatkozó hiányos információk azonban megnehezítik az ízesítőanyagok vizsgálatát. Általánosságban megállapítható, hogy magasabb ízesítőanyag-tartalom magasabb toxicitással jár együtt.

\section{A NIKOTINMENTES ÉS A NIKOTINTARTALMÚ E-CIGARETTA HATÁSAI}

A legtöbb e-cigaretta és utántöltő folyadék nikotintartalmú. A nikotintartalmú aeroszol növeli a szívfrekvenciát, az artériák merevségét, rontja az endotél múködését, így akadályozza a mikrocirkulációt, és emeli a vérnyomást. Egyes vizsgálatok a nikotintartalomtól függetlenül kimutattak szív- és érrendszeri hatásokat.

\section{AZ E-CIGARETTA EGYÉB VESZÉLYEI}

\section{A nikotintartalom pontatlan feltüntetése}

Számos tanulmány kimutatta, hogy az utántöltő folyadékok nikotin koncentrációi gyakran jelentősen eltérnek a csomagoláson feltüntetett értékektől. Minőségellenőrzés hiányában nem meglepőek a pontatlanságok, ráadásul nagyon sok vezető márkát hamisítanak is. A leginkább aggasztó, hogy számos esetben a nikotinmentesnek feltüntetett folyadékban is találtak nikotint, akár $20 \mathrm{mg} / \mathrm{ml}$ feletti koncentrációban.

\section{Az e-cigaretta felrobbanásából eredő veszélyek}

Az e-cigaretta használatával kapcsolatos további veszélyforrás, hogy az eszköz spontán felrobbanhat. Számos alkalommal beszámoltak az e-cigaretta felrobbanásából eredő sérülésekről, amely egy ismert esetben halállal végződött. A robbanás leginkább a lítium-ion akkumulátorok túlmelegedésének tulajdonítható, amely hibás vagy a felhasználó által átalakított akkumulátor következménye lehet. Felrobbanhat az eszköz akkor is, ha az akkumulátort fémtárggyal érintkezve tárolják, és rövidzárlat alakul ki.

Az esettanulmányok beszámoltak használat közbeni felrobbanásokról, amely száj- és arcsérüléseket, a fogak és az arccsont törését okozták. Ismertek továbbá a nadrágban vagy mellzsebben tárolt e-cigaretta felrobbanása miatti égési sérülések, melyek egyes esetekben mútétet és bőrátültetést is igényeltek.

\section{Az e-cigaretta daganatkeltő kockázata}

Az e-cigaretta által előállított aeroszol egyes összetevőinek in vitro mutagén és DNS-károsító hatása bizonyított. Egyes ismert rákkeltő anyagok, mint a formaldehid és az akrolein a hagyományos cigarettafüstnél ugyan alacsonyabb mértékben találhatók az e-cigaretta párájában, azonban egyelőre nincs kellőképpen feltárva, hogy ez mit jelent a daganatkeltő kockázat szempontjából. 


\section{TANULSÁGOK A HAZAI SZAKEMBEREK SZÁMÁRA}

A társadalom és az egészségügyi dolgozók részéről egyaránt határozott változásra van szükség a dohányzás megítélésében, beleértve az új típusú dohánytermékeket is. Azokban a társadalmakban, ahol komoly korlátozások segítették a nemdohányzók védelmét, valamint ösztönzést kapott a dohányzás hátrányos társadalmi megítélése (óvodai-iskolai egészségfejlesztés, dohánytermékek egységes csomagolása, reklámozás tiltása, jövedéki adópolitika), számottevő eredményeket értek el a megelőzésben és a leszokásban.

Magyarországon még számos feladat megoldásra vár, pl. a dohányzás korlátozásának betartatása az egészségügyi intézmények területén. További jelentős eredményekre vezetne, ha szakmai elvárás lenne valamennyi alap- és szakellátással, valamint gondozással foglalkozó egészségügyi intézményben a leszokást támogató konkrét segítségnyújtás, és ha minden egészségügyi ellátásban részesülő dohányzó beteg automatikusan segítséget kaphatna a leszokáshoz képzett és motivált egészségügyi dolgozóktól, akik szükség szerint a függőség kezelését segítő, megfelelő gyógyszerekkel is a betegek rendelkezésére állnak. Az egészségfejlesztő intézmények feladata pedig az, hogy tegyenek további erőfeszítéseket, és teremtsenek újabb eszközöket a dohányipar káros reklámtevékenységének ellensúlyozására, és az új termékek káros hatásának tudatosítására. 